Bull. Chem. Soc. Ethiop. 2014, 28(1), 29-36.

Printed in Ethiopia

DOI: http://dx.doi.org/10.4314/bcse.v28i1.4

ISSN 1011-3924

(c) 2014 Chemical Society of Ethiopia

\title{
SYNTHESES, SPECTROSCOPIC AND MAGNETIC PROPERTIES OF POLYSTYRENE-ANCHORED COORDINATION COMPOUNDS OF THIAZOLIDINONE
}

\author{
Dinesh Kumar ${ }^{1}$, Amit Kumar ${ }^{2 *}$ and Durga Dass ${ }^{3}$ \\ ${ }^{1}$ Department of Chemistry, National Institute of Technology, Kurukshetra 136119, Haryana, \\ India \\ ${ }^{2}$ Department of Chemistry, Haryana College of Technology \& Management, Kaithal, 136027, \\ Haryana, India \\ ${ }^{3}$ Department of Chemistry, Shri Krishan Institute of Engineering \& Technology, Kurukshetra \\ 136118, Haryana, India
}

(Received October 31, 2012; revised June 13, 2013)

\begin{abstract}
The reaction between polystyrene 3-formylsalicylate and furoic acid hydrazide in DMF in the presence of ethyl acetate results in the formation of polystyrene $\mathrm{N}$-(2-carbamoylfuranyl)-3'-carboxy-2'hydroxybenzylideneimine (I). A benzene suspension of $\mathbf{I}$ reacts with mercaptoacetic acid and forms the polystyrene $\mathrm{N}$-(2-carbamoylfuranyl)-C-(3'-carboxy-2'-hydroxyphenyl)thiazolidin-4-one, $\mathrm{PSCH}_{2}-\mathrm{LH}_{2}$ (II). A DMF suspension of II reacts with $\mathrm{Mn}$ (II), $\mathrm{Ni}(\mathrm{II}), \mathrm{Cd}(\mathrm{II}), \mathrm{Fe}$ (III) and $\mathrm{UO}_{2}$ (VI) ions and forms the polystyrene-anchored coordination compounds of the types, $\left[\mathrm{PSCH}_{2}-\mathrm{LMn}(\mathrm{DMF})_{3}\right],\left[\mathrm{PSCH}_{2}-\mathrm{LNi}(\mathrm{DMF})_{3}\right], \quad\left[\mathrm{PSCH}_{2}-\mathrm{LCd}(\mathrm{DMF})\right]$, $\left[\mathrm{PSCH}_{2}-\mathrm{LH}_{2} \mathrm{FeCl}_{3}\right]$ and $\left[\mathrm{PSCH}_{2}-\mathrm{LHUO}_{2}\left(\mathrm{NO}_{3}\right)(\mathrm{DMF})\right]$. The polystyrene-anchored coordination compounds have been characterized on the basis of elemental analyses, spectral (IR, reflectance) studies and magnetic susceptibility measurements. II acts as a neutral tridentate $\mathrm{ONO}$ donor ligand in $\left[\mathrm{PSCH}_{2}-\mathrm{LH}_{2} \mathrm{FeCl}_{3}\right]$, a monobasic tridentate $\mathrm{ONO}$ donor ligand in $\left[\mathrm{PSCH}_{2}-\mathrm{LHUO}_{2}\left(\mathrm{NO}_{3}\right)(\mathrm{DMF})\right]$, a dibasic tridentate ONO donor ligand in $\left[\mathrm{PSCH}_{2}-\mathrm{LMn}(\mathrm{DMF})_{3}\right],\left[\mathrm{PSCH}_{2}-\mathrm{LNi}(\mathrm{DMF})_{3}\right]$ and $\left[\mathrm{PSCH}_{2}-\mathrm{LCd}(\mathrm{DMF})\right]$. A tetrahedral structure for $\mathrm{Cd}(\mathrm{II})$ and an octahedral structure for $\mathrm{Mn}(\mathrm{II}), \mathrm{Ni}(\mathrm{II}), \mathrm{Fe}(\mathrm{III})$ and a square-antiprism geometry for $\mathrm{UO}_{2}$ (VI) complex are suggested.
\end{abstract}

KEY WORDS: Thiazolidin-4-one, Polystyrene-anchored coordination compounds, Magnetic susceptibility, Complexometric, Magnetically dilute

\section{INTRODUCTION}

There has been considerable interest in the synthesis and use of functionalized polymers having chelating abilities in recent years due to their practical convenience, operational flexibility and formation of coordination with high metal to polymer bond energies [1]. Chloromethylated styrene-divinylbenzene copolymer, in particular, is one of the most widely employed macromolecular supports for the synthesis of functionalized polymers. Heterogenization or immobilization of active metal complexes on polymeric supports has evolved as a promising strategy for combining the advantages of homogeneous and heterogeneous catalysts due to their easy isolation from the products by filtration and the possibility of recycling them or continuous operation in a reactor [2]. A structural study of polymer-anchored compounds seems useful in view of their numerous applications in analytical chemistry [3], metal ion removal [4], immobilization of enzymes [5], antimicrobial activities [6], as catalysts [7-8], as solid supports [9], as substrate carriers [10] and as ion-exchanger [11], etc.

Thiazolidin-4-ones belong to an important group of heterocyclic compounds with carbonyl group at fourth position. They show broad spectrum of biological activities due to their ready

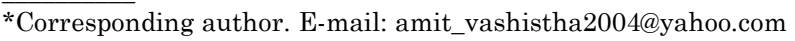


accessibility and diverse chemical reactivity [12, 13]. They are involved in variety of applications such as antimicrobial, antibacterial, anticonvulsant, antifungal, anti-HIV, antiproliferative, anti-inflammatory, cystic fibrosis and antithyroid [14], etc. Many drugs possess modified pharmacological properties in the form of the metal complexes [15].

These facts prompted us to explore the coordination behavior of thiazolidin-4-one (II) derived from the Schiff base (I) (obtained from the condensation of polystyrene 3formylsalicylate and furoic acid hydrazide) towards $\mathrm{Mn}(\mathrm{II}), \mathrm{Ni}(\mathrm{II}), \mathrm{Cd}(\mathrm{II}), \mathrm{Fe}(\mathrm{III})$ and $\mathrm{UO}_{2}(\mathrm{VI})$ ions.

A perusal of the literature indicates that several polymer-anchored ligands containing oxygen atom(s) like crown ethers [16], Imidazole [17], iminodiacetic acid [18] and iminodipropionic acid, amino acid [19] have been reported. However, there is less number of papers available on the coordination compounds of thiazolidin-4-one moiety [20].

In this paper, we describe the syntheses and characterization of polystyrene-anchored thiazolidin-4-one, $\mathrm{PSCH}_{2}-\mathrm{LH}_{2}$ (II) and its coordination compounds with $\mathrm{Mn}(\mathrm{II}), \mathrm{Ni}(\mathrm{II}), \mathrm{Cd}(\mathrm{II})$, $\mathrm{Fe}(\mathrm{III})$ and $\mathrm{UO}_{2}(\mathrm{VI})$ ions. The structures of $\mathbf{I}$ and $\mathbf{I I}$ is represented in Figure 1.

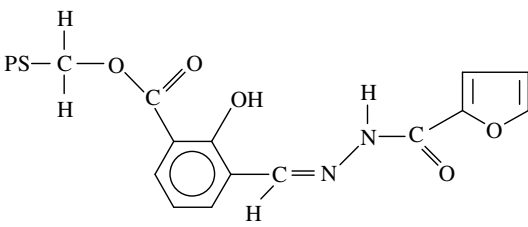

[I (keto-form)]

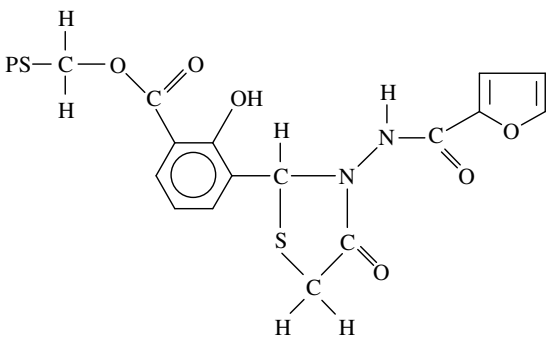

[II (keto-form)]

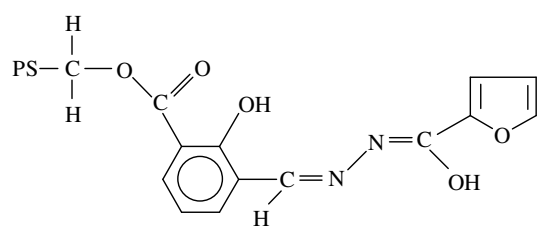

[I (enol-form)]

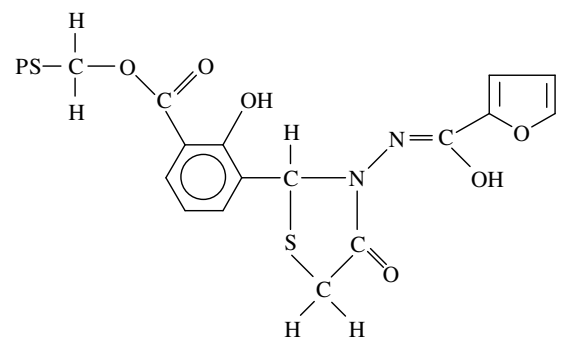

[II (enol-form)]

Figure 1. Structure of $\mathbf{I}$ and $\mathrm{PSCH}_{2}-\mathrm{LH}_{2}$ (II).

\section{EXPERIMENTAL}

\section{Materials}

Chloromethylated polystyrene, $\mathrm{PSCH}_{2}-\mathrm{Cl}$ (containing $1.17 \mathrm{mmol}$ of $\mathrm{Cl}$ per $\mathrm{g}$ of resin and $1 \%$ crosslinked with divinylbenzene) [Sigma Chemical Co., USA], manganese(II) acetate tetrahydrate, nickel(II) acetate tetrahydrate, cadmium(II) acetate dihydrate, uranyl nitrate dihydrate, iron(III) chloride (anhydrous) [Sarabhai, India]; mercaptoacetic acid, dry benzene, sodium bicarbonate, ethyl acetate [Ranbaxy, India] and DMF [s d fine-chem Limited, India] 
were used as received for the syntheses. Polystyrene 3-formylsalicylate was synthesized by following the reported procedure [21].

\section{Analyses and physical measurements}

A known weight ( $1.0 \mathrm{~g}$ ) of the polystyrene-anchored coordination compound of $\mathrm{Mn}$ (II), $\mathrm{Ni}$ (II) and $\mathrm{Cd}(\mathrm{II})$ ions was warmed slowly with $6 \mathrm{M} \mathrm{CH}_{3} \mathrm{COOH}$. The organic skeleton left was filtered off and then washed repeatedly with hot $2 \mathrm{M} \mathrm{CH}_{3} \mathrm{COOH}$ and distilled water. The leached $\mathrm{Mn}(\mathrm{II}), \mathrm{Ni}(\mathrm{II})$ and $\mathrm{Cd}(\mathrm{II})$ ions were estimated by complexometric titration method against standardized EDTA solution using eriochrome black-T, murexide and xylenol orange as indicators respectively. The Fe(III) compound was leached with $6 \mathrm{~N} \mathrm{HCl}$. The organic skeleton left was filtered off, washed thoroughly with $2 \mathrm{M} \mathrm{HCl}$ followed by hot distilled water. The leached $\mathrm{Fe}$ (III) ions were reduced to $\mathrm{Fe}$ (II) with aqueous $\mathrm{SnCl}_{2}$ and then were estimated against standard $\mathrm{K}_{2} \mathrm{Cr}_{2} \mathrm{O}_{7}$ solution using $\mathrm{N}$-phenylanthranilic acid as an indicator. The estimation of $\mathrm{U}$ was carried out gravimetrically as $\mathrm{U}_{3} \mathrm{O}_{8}$ after decomposing the compound with a few drops of conc. $\mathrm{HNO}_{3}$ and then igniting the residue. The coordinated DMF molecules were determined by heating the corresponding polystyrene-anchored coordination compound in an air oven at a definite temperature for $3 \mathrm{~h}$. DMF was completely lost between $160-225{ }^{\circ} \mathrm{C}$ respectively on heating the compounds of $\mathrm{Mn}(\mathrm{II}), \mathrm{Ni}(\mathrm{II}), \mathrm{Cd}(\mathrm{II})$ and $\mathrm{UO}_{2}(\mathrm{VI})$ ions. The IR spectra of II and its coordination compounds were recorded using $\mathrm{KBr}$ pellets $\left(4000-400 \mathrm{~cm}^{-1}\right)$ on a Nicolet Fourier transform infrared spectrophotometer calibrated with polystyrene. The diamagnetic corrections were computed by following a procedure specially designed for the polystyrene-anchored coordination compounds [21]. The reflectance spectra were recorded on a Beckmann DU spectrophotometer attached with a reflectance arrangement. The magnetic susceptibility measurements were carried out at room temperature, using $\mathrm{Hg}\left[\mathrm{Co}(\mathrm{NCS})_{4}\right]$ as the standard [22]. The diamagnetic corrections were computed using Pascal's constants. The magnetic susceptibilities were corrected for temperature independent paramagnetism term (TIP) [22] using value of $200 \times 10^{-6}$ cgs units for $\mathrm{Ni}(\mathrm{II})$, zero for $\mathrm{Mn}$ (II) and $\mathrm{Fe}(\mathrm{III})$ ions.

Synthesis of polystyrene N-(2-carbamoylfuranyl)-3'-carboxy-2'-hydroxybenzylideneimine (I)

Polystyrene 3-formylsalicylate ( $\left.\mathrm{PSCH}_{2}-\mathrm{Fsal}\right)(1.0 \mathrm{~g})$ was allowed to suspend and swell in DMF $(100 \mathrm{~mL})$ for $45 \mathrm{~min}$. To this suspension, a DMF solution $(60 \mathrm{~mL})$ of furoic acid hydrazide $(0.59 \mathrm{~g}, 4.68 \mathrm{mmol})$ and ethyl acetate $(100 \mathrm{~mL})$ were added, while stirring magnetically. The mixture was refluxed for $8 \mathrm{~h}$ and then was cooled to room temperature. The polystyreneanchored Schiff base, I obtained was suction filtered, washed with DMF and ethyl acetate. It was dried in vacuo at room temperature.

Synthesis of polystyrene $N$-(2-carbamoylfuranyl)-C-(3'-carboxy-2'-hydroxy-phenyl) thiazolidin4-one, $\mathrm{PSCH}_{2}-\mathrm{LH}_{2}(\mathrm{II})$

Mercaptoacetic acid $(0.32 \mathrm{~g}, 3.51 \mathrm{mmol})$ was added to the swollen suspension of $\mathbf{I}(1.0 \mathrm{~g})$ in benzene $(100 \mathrm{~mL})$. The mixture was refluxed for $12 \mathrm{~h}$ on a water bath and then cooled to room temperature. The solid product was washed with $10 \%$ sodium bicarbonate solution followed by chilled distilled water. The product was dried as mentioned above. IR bands $(\mathrm{KBr}): 1690 \mathrm{~cm}^{-1}$ $[v(\mathrm{C}=\mathrm{O})$ (thiazolidinone ring) $], 1650 \mathrm{~cm}^{-1}[v(\mathrm{C}=\mathrm{O})($ amide $)], 1575 \mathrm{~cm}^{-1}[v(\mathrm{C}-\mathrm{N})$ (thiazolidinone ring $)], 1535 \mathrm{~cm}^{-1}[v(\mathrm{C}-\mathrm{O})($ phenolic $)], 1085 \mathrm{~cm}^{-1}[v(\mathrm{C}-\mathrm{O}-\mathrm{C})($ furan ring $)]$ and $830 \mathrm{~cm}^{-1}[v(\mathrm{C}-$ $-\mathrm{S})$ (thiazolidinone ring)]. 
Syntheses of coordination compounds of II

$1.0 \mathrm{~g}$ of II was allowed to suspend and swell in DMF $(100 \mathrm{~mL})$ for $1 \mathrm{~h}$. A DMF solution of appropriate metal salt $(2.34 \mathrm{mmol})$ was added to the above suspension. The mixture was refluxed on water bath for $8-10 \mathrm{~h}$ and the products obtained were suction filtered, washed several times with ethyl acetate and DMF. The products were then dried as mentioned above.

\section{RESULTS AND DISCUSSION}

The reaction between polystyrene 3-formylsalicylate and furoic acid hydrazide in DMF in the presence of ethyl acetate results in the formation of polystyrene N-(2-carbamoylfuranyl)-3'carboxy-2'-hydroxybenzylideneimine (I). DMF was selected as a solvent because it has high dielectric constant and is more effective in swelling of chloromethylated polystyrene. The cyclization of I with mercaptoacetic acid in benzene results in the formation of the polystyrene $\mathrm{N}$-(2-carbamoylfuranyl)-C-(3'-carboxy-2'-hydroxyphenyl)thiazolidin-4-one, $\mathrm{PSCH}_{2}-\mathrm{LH}_{2}$ (II). A DMF suspension of II reacts with $\mathrm{Mn}(\mathrm{II}), \mathrm{Ni}(\mathrm{II}), \mathrm{Cd}(\mathrm{II}), \mathrm{Fe}(\mathrm{III})$ and $\mathrm{UO}_{2}$ (VI) ions in 1:2 molar ratio and forms the polystyrene-anchored coordination compounds of the types, $\left[\mathrm{PSCH}_{2}-\right.$ $\left.\mathrm{LMn}(\mathrm{DMF})_{3}\right],\left[\mathrm{PSCH}_{2}-\mathrm{LNi}(\mathrm{DMF})_{3}\right],\left[\mathrm{PSCH}_{2}-\mathrm{LCd}(\mathrm{DMF})\right],\left[\mathrm{PSCH}_{2}-\mathrm{LH}_{2} \mathrm{FeCl}_{3}\right]$ and $\left[\mathrm{PSCH}_{2}-\right.$ $\left.\mathrm{LHUO}_{2}\left(\mathrm{NO}_{3}\right)(\mathrm{DMF})\right]$. The percent reaction conversion of these compounds lies between 46.780.4 and the metal binding capacity of II lies between $0.32-0.60 \mathrm{mmol}$ per $\mathrm{g}$ of the resin (Table 1). The formation of I, II and the coordination compounds of II occurs as per Schemes 1, 2 and 3 , respectively.

Table 1. Analytical, MBC and PRC values of polystyrene-anchored coordination compounds of $\mathbf{I I}^{\mathrm{a}}$.

\begin{tabular}{|l|c|c|c|c|}
\hline Compound & \multicolumn{2}{|c|}{ Obsd (calcd)\% } & $\begin{array}{c}\mathrm{MBC}^{\mathrm{b}} \mathrm{mmol} / \mathrm{g} \text { of } \\
\text { resin }\end{array}$ & $\mathrm{PRC}^{\mathrm{c}}$ \\
\hline & $\mathrm{M}$ & DMF & & \\
\hline$\left[\mathrm{PSCH}_{2}-\mathrm{LMn}(\mathrm{DMF})_{3}\right]$ & $2.7(3.82)$ & $10.7(15.23)$ & 0.49 & 70.7 \\
\hline$\left[\mathrm{PSCH}_{2}-\mathrm{LNi}(\mathrm{DMF})_{3}\right]$ & $1.9(4.07)$ & $7.3(15.19)$ & 0.32 & 46.7 \\
\hline$\left[\mathrm{PSCH}_{2}-\mathrm{LCd}(\mathrm{DMF})\right]$ & $6.7(8.33)$ & $4.3(5.41)$ & 0.60 & 80.4 \\
\hline$\left[\mathrm{PSCH}_{2}-\mathrm{LH}_{2} \mathrm{FeCl}_{3}\right]$ & $2.2(4.21)$ & - & 0.39 & 52.2 \\
\hline$\left[\mathrm{PSCH}_{2}-\mathrm{LHUO}_{2}\left(\mathrm{NO}_{3}\right)(\mathrm{DMF})\right]$ & $8.8(15.17)$ & $2.7(4.65)$ & 0.37 & 58.0 \\
\hline
\end{tabular}

${ }^{\mathrm{a}}$ Abbreviations: $\mathrm{PSCH}_{2}-\mathrm{LH}_{2}=$ II. ${ }^{\mathrm{b}} \mathrm{MBC}=[\mathrm{M} \%$ (observed) $\times 10] /\left(\right.$ atomic weight of metal). ${ }^{\mathrm{c}} \mathrm{PRC}=[\mathrm{M} \%$ (observed) $\times 100 \mathrm{~J} / \mathrm{M} \%$ (calculated) on the basis of $100 \%$ reaction conversion of polystyrene-anchored ligand to polystyrene-anchored coordination compounds.

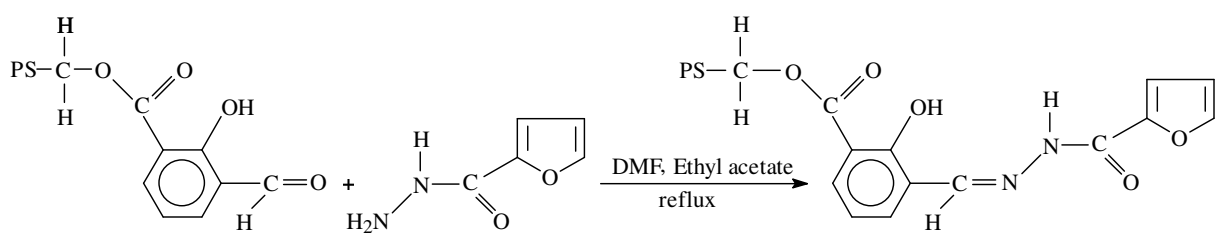

Scheme 1. Preparation of polystyrene N-(2-carbamoylfuranyl)-3'-carboxy-2'-hydroxybenzylideneimine (I).

Bull. Chem. Soc. Ethiop. 2014, 28(1) 


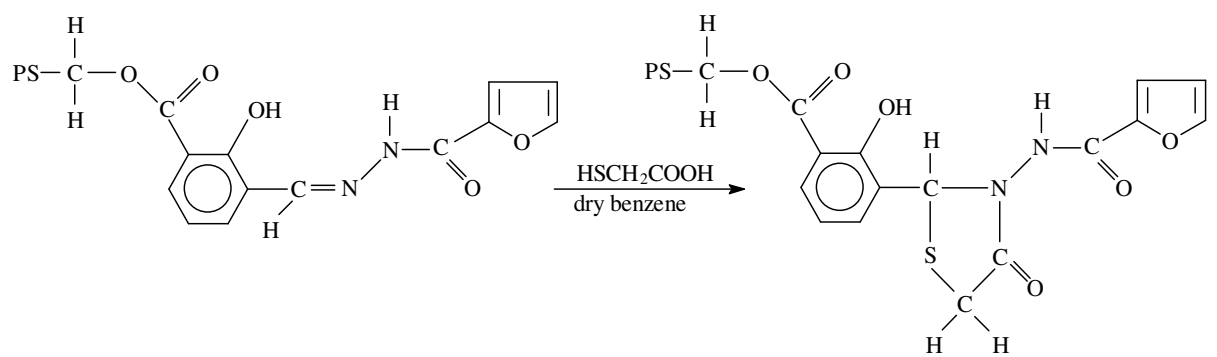

Scheme 2. Preparation of polystyrene N-(2-carbamoylfuranyl)-C-(3'-carboxy-2'-hydroxyphenyl) thiazolidin-4-one, $\mathrm{PSCH}_{2}-\mathrm{LH}_{2}$ (II).

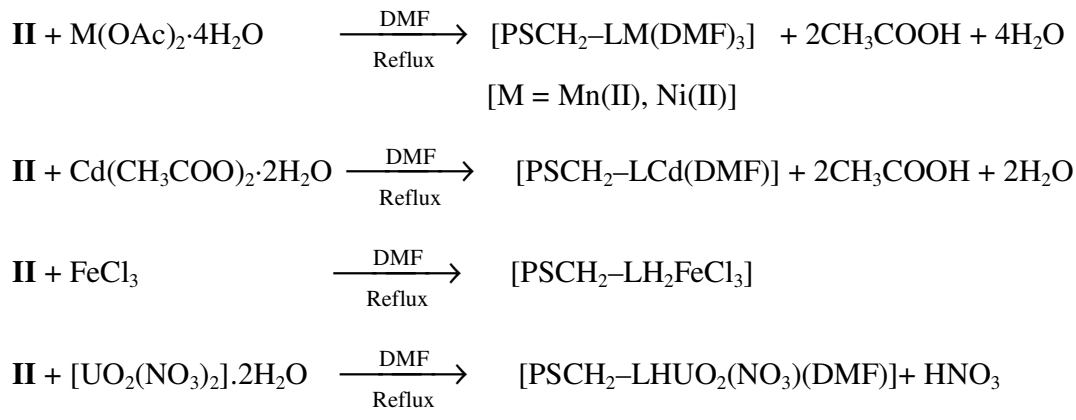

Scheme 3. Preparation of polystyrene-anchored coordination compounds.

\section{Infrared spectral studies}

The infrared spectra of $\mathrm{PSCH}_{2}-\mathrm{LH}_{2}$ (II) and its coordination compounds were recorded in $\mathrm{KBr}$ and the prominent peaks are shown in Table 2. The $v(\mathrm{C}=\mathrm{N})$ (azomethine) stretch of $\mathbf{I}$ occurs at $1620 \mathrm{~cm}^{-1}$. This band disappears and a new band appears in II at $1575 \mathrm{~cm}^{-1}$ due to the $v(\mathrm{C}-\mathrm{N})$ (thiazolidinone ring) stretch [23] indicating the formation of corresponding thiazolidinone. The formation of II is further supported by the appearance of a new band at 830 $\mathrm{cm}^{-1}$ due to the $v(\mathrm{C}-\mathrm{S})$ (thiazolidinone ring) stretch [24]. II occurs in the keto-form [25] as evident by the presence of a strong band due to the $v(\mathrm{C}=\mathrm{O})$ (amide) stretch at $1650 \mathrm{~cm}^{-1}$. This band remains almost at the same energy in $\mathrm{Fe}(\mathrm{III})$ and $\mathrm{UO}_{2}(\mathrm{VI})$ compounds indicating the noninvolvement of the keto $\mathrm{O}$ atom towards coordination. The $\mathrm{Cd}(\mathrm{II}), \mathrm{Mn}$ (II) and $\mathrm{Ni}$ (II) compounds do not display the $v(\mathrm{C}=\mathrm{O})$ (amide) stretch but show a new band between $1235-1260 \mathrm{~cm}^{-1}$ suggesting the conversion of $-\mathrm{C}(\mathrm{O}) \mathrm{NH}-$ moiety (keto-form) into $-\mathrm{C}(\mathrm{OH})=\mathrm{N}-$ moiety (enolform) followed by the deprotonation of enolic $\mathrm{OH}$ group and subsequently involvement of enolic $\mathrm{O}$ atom towards coordination. The $v(\mathrm{C}-\mathrm{O}) \phi$ stretch [25] of II occurs at $1535 \mathrm{~cm}^{-1}$. This band remains unchanged in the $\mathrm{Fe}(\mathrm{III})$ and $\mathrm{UO}_{2}(\mathrm{VI})$ compounds indicating the non-involvement of phenolic $\mathrm{O}$ atom towards coordination. However, the shifting of this band towards higher energy $\left(\leq 10 \mathrm{~cm}^{-1}\right)$ in the remaining compounds favours the formation of a bond between phenolic $\mathrm{O}$ atom and the corresponding metal ions. The $v(\mathrm{C}=\mathrm{O})$ (thiazolidinone) stretch [26] of II occurs at $1690 \mathrm{~cm}^{-1}$. This band shows a negative shift by $30-50 \mathrm{~cm}^{-1}$ in the Fe(III) and $\mathrm{UO}_{2}$ (VI) compounds indicating the coordination through $\mathrm{O}$ atom of the carbonyl group of thiazolidinone moiety. The occurrence of this band almost at the same energy in the remaining compounds indicates the non-involvement of the carbonyl $\mathrm{O}$ atom towards coordination. The $\left[v(\mathrm{C}-\mathrm{N})\right.$ (thiazolidinone ring)] stretch [23] of II shifts from $1575 \mathrm{~cm}^{-1}$ to lower energy by $28-34$ 
$\mathrm{cm}^{-1}$ in the $\mathrm{Mn}$ (II), $\mathrm{Ni}$ (II) and $\mathrm{Cd}(\mathrm{II})$ compounds lending support for the involvement of ring $\mathrm{N}$ atom towards coordination. However, this band remains almost at the same energy in the remaining compounds. The $[v(\mathrm{C}-\mathrm{S})$ (thiazolidinone ring)] stretch [24] of II occurred at 830 $\mathrm{cm}^{-1}$. This band remains unchanged in the compounds indicating the non-involvement of $\mathrm{S}$ atom towards the coordination. The $v(\mathrm{C}--\mathrm{O}--\mathrm{C})$ (furan ring) stretch [27] of II occurring at $1085 \mathrm{~cm}^{-1}$ shifts to lower energy by 60 and $70 \mathrm{~cm}^{-1}$ in $\mathrm{Fe}(\mathrm{III})$ and $\mathrm{UO}_{2}$ (VI) compounds respectively. On the other hand, it remains unchanged in the remaining compounds. DMF shows a band at $1675 \mathrm{~cm}^{-1}$ due to the $v(\mathrm{C}=\mathrm{O})$ stretch [28]. This band shifts to lower energy by $20-38 \mathrm{~cm}^{-1}$ in $\mathrm{Cd}$ (II), $\mathrm{Mn}$ (II), $\mathrm{Ni}(\mathrm{II})$ and $\mathrm{UO}_{2}(\mathrm{VI})$ compounds indicating the involvement of $\mathrm{O}$ atom towards coordination [28]. The absence of a band between $820-860 \mathrm{~cm}^{-1}$ in the Fe(III) compound, precludes the presence of a $(\mathrm{Fe}-\mathrm{O}-\mathrm{Fe})$ bridged structure [28]. [ $\left.\mathrm{PSCH}_{2}-\mathrm{LHUO}_{2}\left(\mathrm{NO}_{3}\right)(\mathrm{DMF})\right]$ exhibits the $v_{\text {as }}(\mathrm{O}=\mathrm{U}=\mathrm{O})$ stretch at $908 \mathrm{~cm}^{-1}$ and this band occurs in the usual range $\left(870-950 \mathrm{~cm}^{-1}\right)$ observed for the majority of trans- $\mathrm{UO}_{2}$ compounds [29]. The force constant $\left(\mathrm{f}_{\mathrm{U}-\mathrm{O}}\right)$ and the $\mathrm{U}-\mathrm{O}$ bond length are $6.85 \mathrm{mdyn} / \AA$ and $1.74 \AA$. These values are in the expected ranges $(6.58-7.03 \mathrm{mdyn} / \AA$ and 1.60-1.92 $\AA$ ) reported for the majority of $\mathrm{UO}_{2}(\mathrm{VI})$ compounds [29].

Table 2. IR, reflectance spectral $\left(\mathrm{cm}^{-1}\right)$ and magnetic moments values of polystyrene-anchored coordination compounds.

\begin{tabular}{|c|c|c|c|c|c|c|c|}
\hline Compound & $v(\mathrm{C}-\mathrm{O}) \Phi$ & $\begin{array}{c}v(\mathrm{C}-\mathrm{N}) \\
\text { (thiazoli- } \\
\text { dinone) }\end{array}$ & $\begin{array}{l}v(\mathrm{C}-\mathrm{O}) \\
(\text { enolic })\end{array}$ & \begin{tabular}{|c|}
$v(\mathrm{C}-\mathrm{O}-\mathrm{C})$ \\
(furan ring)
\end{tabular} & $\begin{array}{l}v(\mathrm{C}=\mathrm{O}) \\
(\mathrm{DMF})\end{array}$ & $V_{\max }$ & $\begin{array}{c}\text { Mag. } \\
\text { moment } \\
\text { (B.M.) }\end{array}$ \\
\hline $\mathrm{PSCH}_{2}-\mathrm{LH}_{2}(\mathrm{II})$ & 1535 & 1575 & - & 1085 & - & - & Diamag. \\
\hline$\left[\mathrm{PSCH}_{2}-\mathrm{LMn}(\mathrm{DMF})_{3}\right]$ & 1542 & 1547 & 1235 & 1085 & 1655 & $\begin{array}{c}18330,22820, \\
25260\end{array}$ & 5.88 \\
\hline$\left[\mathrm{PSCH}_{2}-\mathrm{LNi}(\mathrm{DMF})_{3}\right]$ & 1543 & 1541 & 1260 & 1085 & 1650 & $\begin{array}{c}9320,16150, \\
24580\end{array}$ & 3.15 \\
\hline$\left[\mathrm{PSCH}_{2}-\mathrm{LCd}(\mathrm{DMF})\right]$ & 1545 & 1545 & 1255 & 1085 & 1640 & - & Diamag. \\
\hline$\left[\mathrm{PSCH}_{2}-\mathrm{LH}_{2} \mathrm{FeCl}_{3}\right]$ & 1535 & 1574 & - & 1025 & - & $\begin{array}{c}12270,16300, \\
24700\end{array}$ & 5.90 \\
\hline$\left[\mathrm{PSCH}_{2}-\mathrm{LHUO}_{2}\left(\mathrm{NO}_{3}\right)(\mathrm{DMF})\right]$ & 1535 & 1576 & - & 1015 & 1637 & - & Diamag. \\
\hline
\end{tabular}

\section{Reflectance spectral studies}

The electronic spectra of the compounds could not be recorded in the nujol mull as the polystyrene-anchored compounds do not form a good mull. Therefore, the reflectance spectra of these compounds were recorded (Table 2). The compounds being insoluble in common solvents, their solution electronic spectra also could not be recorded. [ $\left.\mathrm{PSCH}_{2}-\mathrm{LMn}(\mathrm{DMF})_{3}\right]$ exhibits three bands at 18330,22820 and $25260 \mathrm{~cm}^{-1}$ due to ${ }^{6} A_{1 \mathrm{~g}} \rightarrow{ }^{4} T_{1 \mathrm{~g}}(G),{ }^{6} A_{1 \mathrm{~g}} \rightarrow{ }^{4} T_{2 \mathrm{~g}}(G)$ and ${ }^{6} A_{1 \mathrm{~g}} \rightarrow{ }^{4} A_{1 \mathrm{~g}}(G)$ transitions, respectively in an octahedral environment [30]. [ $\mathrm{PSCH}_{2}-$ $\mathrm{LNi}(\mathrm{DMF})_{3}$ ] exhibits three bands at 9320,16150 and $24580 \mathrm{~cm}^{-1}$ due to the ${ }^{3} A_{2 \mathrm{~g}}(F) \rightarrow$ ${ }^{3} T_{2 \mathrm{~g}}(F)\left(v_{1}\right),{ }^{3} A_{2 \mathrm{~g}}(F) \rightarrow{ }^{3} T_{1 \mathrm{~g}}(F)\left(v_{2}\right)$ and ${ }^{3} A_{2 \mathrm{~g}}(F) \rightarrow{ }^{3} T_{1 \mathrm{~g}}(P)\left(v_{3}\right)$ transitions, respectively in an octahedral symmetry [30]. The $v_{2} / v_{1}$ value is 1.73 and lies in the usual range: $1.60-1.82$ reported for majority of octahedral Ni(II) compounds [31]. The spectral parameters are: $D q=932 \mathrm{~cm}^{-1}$, $\mathrm{B}^{\prime}=774 \mathrm{~cm}^{-1}, \beta=0.75$ and $\beta^{0}=25 \%$. The reduction of Racah parameter from the free ion value $1030 \mathrm{~cm}^{-1}$ to $774 \mathrm{~cm}^{-1}$ and $\beta^{0}$ value $(25 \%)$ is indicative of the strong covalent nature of the compound [31]. [ $\mathrm{PSCH}_{2}-\mathrm{LH}_{2} \mathrm{FeCl}_{3}$ ] exhibits three bands at 12270,16300 and 24700 respectively due to the ${ }^{6} A_{1 \mathrm{~g}} \rightarrow{ }^{4} T_{1 \mathrm{~g}}(G),{ }^{6} A_{1 \mathrm{~g}} \rightarrow{ }^{4} T_{2 \mathrm{~g}}(G)$ and ${ }^{6} A_{1 \mathrm{~g}} \rightarrow{ }^{4} A_{1 \mathrm{~g}}(G)$ transitions respectively, in an octahedral symmetry [30].

\section{Magnetic measurements}

The room temperature magnetic moments of the polystyrene-anchored coordination compounds of II are presented in Table 2. [PSCH$\left.{ }_{2}-\mathrm{LMn}(\mathrm{DMF})_{3}\right]$ exhibits magnetic moment 5.88 B.M. and 
it falls in the normal range reported for the majority of high-spin octahedral $\mathrm{Mn}$ (II) compounds [32]. $\left[\mathrm{PSCH}_{2}-\mathrm{LNi}(\mathrm{DMF})_{3}\right.$ ] exhibits magnetic moment 3.15 B.M. which falls in the normal range reported for the octahedral $\mathrm{Ni}$ (II) compounds. This value is also indicative of magnetically dilute nature of the compound [32]. [ $\mathrm{PSCH}_{2}-\mathrm{LH}_{2} \mathrm{FeCl}_{3}$ ] exhibits magnetic moment 5.90 B.M. which falls in the normal range reported for the majority of magnetically dilute $\mathrm{Fe}(\mathrm{III})$ compounds [32]. The $\mathrm{Cd}(\mathrm{II})$ and $\mathrm{UO}_{2}(\mathrm{VI})$ compounds are diamagnetic as expected for the $d^{10}$ or $f^{0}$ systems.

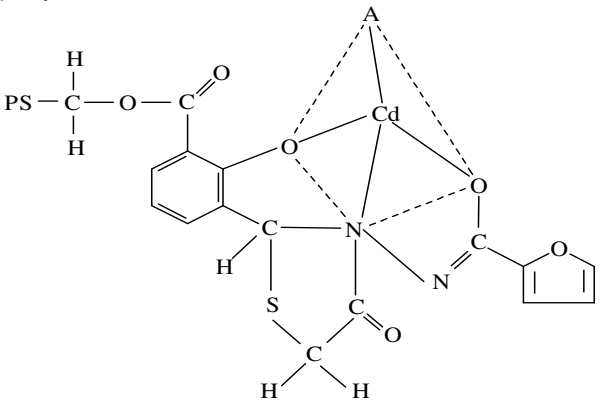

[III, A = DMF]

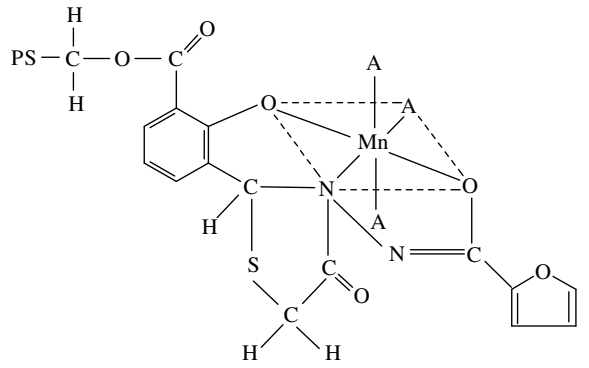

$[\mathrm{IV}, \mathrm{A}=\mathrm{DMF}]$

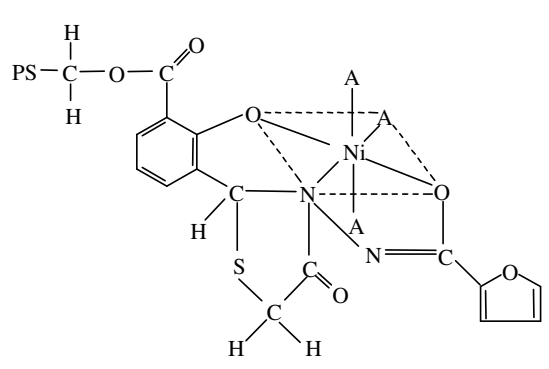

$[\mathbf{V}, \mathrm{A}=\mathrm{DMF}]$

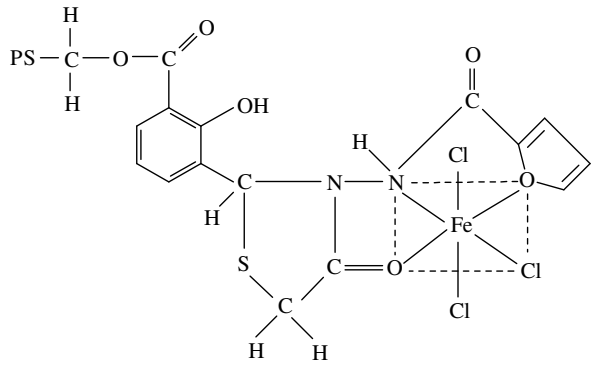

[VI]

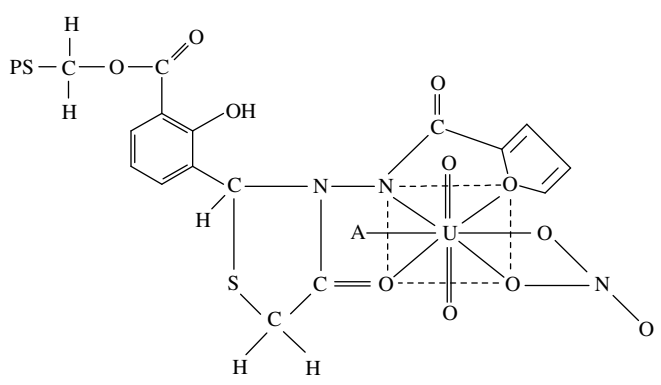

[VII, $\mathrm{A}=\mathrm{DMF}]$

Figure 2. Structure of polystyrene-anchored coordination compounds. 


\section{CONCLUSIONS}

Thus, on the basis of analytical, molecular weight, spectral and magnetic studies, we suggest a tetrahedral structure for $\left[\mathrm{PSCH}_{2}-\mathrm{LCd}(\mathrm{DMF})\right]$ [III], octahedral structure for $\left[\mathrm{PSCH}_{2}-\right.$ $\mathrm{LMn}(\mathrm{DMF})_{3}$ ] [IV], $\left[\mathrm{PSCH}_{2}-\mathrm{LNi}(\mathrm{DMF})_{3}\right][\mathbf{V}]$ and $\left[\mathrm{PSCH}_{2}-\mathrm{LH}_{2} \mathrm{FeCl}_{3}\right]$ [VI] and a squareantiprism geometry for $\left[\mathrm{PSCH}_{2}-\mathrm{LHUO}_{2}\left(\mathrm{NO}_{3}\right)(\mathrm{DMF})\right]$ [VII] . Figure 2 represents the structure of polystyrene-anchored coordination compounds.

\section{REFERENCES}

1. Dhamodaran, M.; Parameswaran, V.R. J. Ind. Council Chem. 2008, 25, 71.

2. Kumar, D.; Syamal, A.; Sharma, L.K. J. Coord. Chem. 2008, 61, 1788.

3. Maurya, M.R.; Kumar, M.; Kumar, U. J. Mol. Catal. A: Chem. 2007, 273, 133.

4. Kumar, K.G.; Saji John, K. React. Funct. Polym. I 2006, 66, 1427.

5. Assmann, A.; Bonifacic, M.; Sies, K.B. Free Radical Res. 2000, 32, 371.

6. Ahamad, T.; Kumar, V.; Parveen, S.; Nishat, N. J. Coord. Chem. 2008, 61, 1423.

7. Gupta, K.C.; Sutar, A.K.; Lin C.C. Coord. Chem. Rev. 2009, 253, 1926.

8. Dhavamani, J.; Dhamodaran, M.; Parameswaran, V.R. Bull. Catal. Soc. India 2006, 5, 164.

9. Zhang, L.; Xu, Y.; Cui, Y. Iran. Polym. J. 2011, 20, 769.

10. Marsh, R.I.; Bradley, M. Tetrahedron 1997, 53, 1731.

11. Iglesias, M.; Antico, E.; Salvado, V. Anal. Chim. Acta 1999, 381, 61.

12. Singh, B.; Maheshwari, A.; Dak, G.; Sharma, K.; Talesara, G.L. Indian J. Pharm. Sci. 2010, $72,607$.

13. Samadhiya, P.; Sharma, R.; Srivastava, S.K. Bull. Chem. Soc. Ethiop. 2013, 27, 249.

14. Choudhari, B.P.; Mulwad, V.V. Indian J. Chem. 2005, 44B, 1074.

15. Panwar, H.; Verma, R.S.; Srivastava, V.; Kumar, A. Indian J. Chem. 2006, 45B, 2088.

16. Brown J., Hamerton I.; Howlin J.B. J. Appl. Polym. Sci. 2000, 72, 201.

17. Mathur, P.N.; Parashar, K.; Srivastava S. Indian J. Chem. 2000, 39A, 1327.

18. Yoshioka, T. Bull. Chem. Soc. Jpn. 1985, 58, 2618.

19. Valodkar, V.B.; Tembe, G.L.; Ravindranathan, M.; Rama, H.S. React. Funct. Polym. 2003, $56,1$.

20. Kumar, D.; Kumar, A. E-J. Chem. 2012, 9, 2532; Rehab, A.M.; Hasani, A.; Sinan, M.M.; Byatti, A.; Sarab, M.S.; Al Azawi, M.S. Engg. Tech. J. 2011, 29, 3067.

21. Syamal, A.; Kumar, D.; Singh, A.K.; Gupta, P.K.; Jaipal; Sharma, L.K. Indian J. Chem. 2002, 41A, 1385.

22. Dutta, R.L.; Syamal A. Elements of Magnetochemistry, 2nd ed., New Delhi: Affiliated East West Press Pvt. Ltd.; 1993.

23. Kumar, D.; Kumar, A.; Sharma J. J. Chem. 2012, 2013, Article ID 870325, 1.

24. Subasi, E.; Ercag, A.; Sert, S.; Senturk, O.S. Synth. React. Inorg. Met.-org. and Nano-Met. Chem. 2006, 36, 705.

25. Kumar, D.; Gupta, P.K.; Kumar, A.; Dass, D.; Syamal, A. J. Coord. Chem. 2011, 64, 590.

26. Junne, S.B.; Wadje, S.S.; Baig, M.M.V.; Vibhute, Y.B. Int. J. Chem. Sci. 2007, 5, 2093.

27. Kumar, D.; Gupta, P.K.; Syamal, A. Indian J. Chem. 2002, 41A, 2494.

28. Kumar, D.; Syamal, A.; Jaipal; Sharma, L. K. J. Chem. Sci. 2009, 121, 57.

29. Kumar, D.; Gupta, P.K.; Syamal, A. J. Chem. Sci. 2005, 117, 247.

30. Lever, A.B.P. Inorganic Electronic Spectroscopy, 2nd ed., Elsevier: Amsterdam; 1984 and references therein.

31. Kumar, D.; Syamal, A.; Sharma, L.K. Elixir Appl. Chem. 2013, 54, 12593.

32. Cotton, F.A.; Wilkinson, G.; Murillo, C.; Bochmann, M. Advanced Inorganic Chemistry, 6th ed., John Wiley and Sons: New York; 1999 and References therein. 